\title{
HUBUNGAN DAYA LEDAK OTOT TUNGKAI, KESEIMBANGAN DAN MOTIVASI DENGAN KETERAMPILAN YEOP CHAGI PADA ATLET TAEKWONDO PELATDA DKI JAKARTA 2015
}

\author{
Reza Irwansyah \\ Akademi Olahraga Prestasi Nasional \\ reza.irwansyah@akornas.ac.id
}

\begin{abstract}
ABSTRAK
Tujuan penelitian ini adalah untuk mencari tahu hubungan antara daya ledak otot tungkai, keseimbangan dan motivasi dengan keterampilan yeop chagi pada atlet Pelatda Taekwondo DKI Jakarta 2015. Sebagai penunjang dalam melakukan latihan para atlet dengan mengetahui komponen-komponen latihannya. Memberikan sumbangan pemikiran bagi pelatih, pembina serta pemain serta informasi wawasan pengetahuan tentang cara meningkatkan keterampilan yeop chagi dalam beladiri taekwondo. Mengetahui hubungan daya ledak otot tungkai, keseimbangan dan motivasi secara bersama-sama dengan keterampilan yeop chagi dalam beladiri taekwondo. Bahan evaluasi bagi Pelatda Taekwondo DKI Jkarta.Sampel penelitian terdiri dari 24 orang dan Sesuai dengan rumusan masalah dan tujuan yang ingin di capai maka metode penelitian yang digunakan dalam penelitian ini adalah deskriptif korelasional

Berdasarkan hasil analisis data penelitian yaitu (1) terdapat hubungan antara daya ledak otot tungkai dengan $\mathrm{r}_{\mathrm{y} 1}=0,88$ dan hubungan daya ledak otot tungkai dengan keterampilan yeop chagi sebesar 77,34\%, diperoleh $t_{\text {hitung }} 8,67>\mathrm{t}_{\text {tabel }} 1,70$, dengan demikian terdapat hubungan antara daya ledak otot tungkai dengan keterampilan yeop chagi, (2) terdapat hubungan antara keseimbangan dengan keterampilan yeop chagi dengan $\mathrm{ry}_{2}=0,603$ dan besarnya hubungan kelincahan dengan menggiring bola sebesar $36,33 \%$. diperoleh $t_{\text {hitung }} 3,54>t_{\text {tabel }} 1,70$, dengan demikian terdapat hubungan keseimbangan dengan keterampilan yeop chagi, (3) terdapat hubungan antara motivasi dengan keterampilan yeop chagi $\mathrm{ry}_{3}=0,634$ dan besarnya hubungan motivasi dengan keterampilan yeop chagi sebesar 40,14\%. diperoleh $t_{\text {hitung }} 3,84>t_{\text {tabel }} 1,70$, dengan demikian terdapat hubungan antara motivasi dengan keterampilan yeop chagi, (4) terdapat hubungan antara daya ledak otot tungkai, keseimbangan dan motivasi dengan keterampilan yeop chagi $\mathrm{rx}_{123} \mathrm{y}=0,745$ dan besarnya hubungan keterampilan yeop chagi sebesar $86,31 \%$.
\end{abstract}

\section{Kata kunci: Daya Ledak Otot Tungkai, Keseimbangan, Motivasi, Yeop Chagi.}

\section{ABSTRACT}

The purpose of this study is to find out as supporting the athletes with exercise to know the components of training. Contribute ideas for trainers, coaches and athletes as well as the insight information about how to improve the skills yeop chagi performance for Pelatda Taekwondo DKI Jakarta. Determine the corelation of the explosive power of leg, balance, and motivation together with yeop chagi performance in the martial art of taekwondo. Evaluation of materials for Pelatda Taekwondo DKI Jakarta. Sample field study consisted of 24 peoples and accordant with the formulation of the problem and the goals you want to accomplish in the research method used in this study is descriptive correlational.

Based on the analysis of research data, namely (1) there is a significant corelation between the explosive power of leg with ry $y_{1}=0.88$ and the explosive power of leg corelation with yeop chagi performance as much as 77,34\%, obtained tarithmetic $8.67>1.70 t_{\text {table, }}$, thus there is a corelation the explosive power of leg corelation with yeop chagi performance, (2) there is a signiifikan between balance to yeop chagi performance with $r y_{2}=0.603$ and balance relationship with yeop chagi performance as much as $63,33 \%$. obtained $t_{\text {arithmetic }} 3,54>t_{\text {table }} 1.70$, thus there 
is a corelation between balance with yeop chagi performance, (3) there is a corelation between motivation with yeop chagi performance r $y_{3}=0.634$ and balance relationship with yeop chagi performance as much as 40,14\%. Obtained tarithmetic $3,84>t_{\text {table }} 1.70$, thus there is a corelation between motivation to yeop chagi performance, (4) There is a signiifikan between the explosive power leg, balance and motivaton with $r x_{123} y=0.745$ and magnitude corelation the explosive power leg, balance and motivaton with yeop chagi performance as much as $76 \%$

\section{Keyword: The Explosive Power of Leg, Balance, Motivaton, Yeop Chagi Performance}

\section{PENDAHULUAN}

Taekwondo merupakan olahraga beladiri yang sudah banyak dikenal di berbagai lapisan masyarakat, hal ini dapat dilihat dari banyaknya masyarakat dari berbagai status sosial yang berlatih taekwondo. Korea adalah Negara yang melahirkan beladiri taekwondo, mulanya taekwondo adalah seni beladiri primitif yang bernama Taek-Kyon pada zaman dinasti Silla.Para prajurit dilatih menggunakan beladiri Taek-Kyon untuk berperang dan hasilnya mereka selalu berhasil dalam setiap pertempuran. Pada tahun 1945 setelah merdeka, orang Korea kemudian melakukan penelitian dari berbagai seni beladiri seperti Taek-Kyon, Karate dari Jepang, Kungfu dari Cina yang setelahnya disusunlah teknikteknik taekwondo yang kita kenal pada saat ini. Dikalangan masyarakat, olahraga ini sangat diminati oleh anak-anak dan remaja, hal ini memberikan dampak yang sangat positif untuk perkembangan beladiri taekwondo.

Pada sidang paripurna XI KONI Pusat 1980, cabang olahraga beladiri taekwondo telah diterima sebagai anggota KONI, tetapi KONI Pusat hanya menginginkan hanya ada satu wadah induk organisasi taekwondo yang berujuk kepada World Taekwondo Federation (WTF) yang bermarkas di Korea Selatan yang juga merupakan anggota dari International Olympic Committee (IOC). Pada saat diadakan Munas Taekwondo Indonesia I, terpilihlah Sarwo Edhie Wibowo sebagai Ketua Umum PBTI periode 1984-1988. Kini taekwondo di Indonesia sudah berjalan beriringan dengan cabang-cabang yang lainnya, berbagai prestasi sudah diperoleh baik di tingkat regional maupun internasional. Taekwondo Indonesia mengirimkan atlet pertamanya yang mengikuti olimpiade pada tahun 2000 di Sidney atas nama Juana Wangsa Putri.

Saat ini WTF mempertandingkan dua nomor pertandingan dalam kejuaraan resmi yaitu kyorugi (pertandingan bebas) dan poomsae (jurus). Dalam tesis ini peneliti hanya berfokus kepada nomor pertandingan kyorugi. Pertandingan kyorugi membutuhkan banyak faktor antara lain, kondisi fisik, teknik, taktik, dan psikologi. Faktor kondisi fisik, teknik danpsikologi adalah unsur yang akan diangkat dalam penelitian ini.

Dari faktor-fakor tersebut salah satu faktor yang harus selalu tetap dilatih dan dikembangkan dengan baik dan benar, yaitu faktor kondisi fisik. Karena kondisi fisik ini merupakan dasar di dalam melatih dan mengembangkan keterampilan atau teknik taekwondoin serta dalam menghadapi pertandingan-pertandingan tetapi harus juga didukung oleh kemapuan mengatur psikologi. Dengan kata lain, seorang taekwondoin harus memiliki kondisi fisik yang relatif baik secara umum dan secara khusus sesuai dengan tuntutan sifat dan karakteristik olahraga taekwondo serta didukung oleh kondisi psikologi yang baik pula.

Taekwondoin tersebut dapat mempertahankan keterampilan atau teknik dengan lebih baik pada saat berlatih maupun pada saat menghadapi pertandinganpertandingan tanpa mengalami kelelahan yang berarti baik fisik maupun mental. Faktor kondisi fisik harus benar-benar mendapatkan perhatian yang serius di dalam program latihan. Faktor kondisi fisik itu terdiri dari beberapa komponen yaitu, kekuatan, daya tahan, daya ledak, ketepatan, kelincahan, koordinasi, keseimbangan, kecepatan, kelentukan dan reaksi. Dimana masing-masing komponen mempunyai 
bentuk latihan yang berbeda, dan banyak pilihan dalam melatihnya.

Peneliti tertarik untuk meneliti faktor kondisi fisik terutama pada unsur daya ledak otot tungkai, dan keseimbangan serta faktor psikologis yang dalam hal ini adalah komponen motivasi sebagaifaktor dalam keterampilanyeop chagi yang saat ini saat efektif digunakan dalam menyerang ataupun bertahan dalam bertanding. Sistem pertandingan terbaru yaitu dengan menggunakan PSS (Protector Scoring System), yaitu body protector yang di hubungkan langsung dengan computer melalui koneksi internet. Dalam peraturan pertandingan yang baru iniyeop chagisangat efektif untuk mendapatkan poin, teknik ini sudah banyak digunakan baik oleh atlet nasional maupun atlet internasional. Hal ini menjadi obyek penelitian mengingat di dalam aplikasinya di lapangan saat iniyeop chagi banyak digunakan dalam menyerang maupun bertahan.Maka atas dasar itu hal ini dijadikan bahan penelitian yaitu daya ledak otot tugkai, keseimbangan, dan motivasi menjadi salah satu dasar dalam keterampilanyeop chagi. Peneliti yang saat ini bekerja sama dengan KONI DKI Jakarta sebagai Strength Conditioning akan menjadikan atlet Pelatda DKI Jakarta sebagai populasi dari penelitian ini agar lebih mudah dalam proses penelitian dan administrasi.

\section{METODE PENELITIAN}

Metode Penelitian yang digunakan dalam penelitian ini adalah penelitian kuantitatif dengan metode deskriptif yaitu melakukan tanpa ada manipulasi oleh variabel tes daya ledak otot tungkai, tes kesimbangan, dan tes motivasi dan keterampilan yeop chagi pada atlet Pelatda Taekwondo DKI Jakarta.

\section{Populasi dan Sampel}

Populasi sasaran (target population) dalam penelitian ini adalah seluruh Atlet Pelatda Taekwondo DKI Jakarta 2015 yang berjumlah 24 orang. Berpedoman pada jumlah populasi diatas, maka pengambilan sampel ditetapkan dengan menggunakan teknik total sampling, yaitu 24 Atlet Pelatda Taekwondo DKI Jakarta 2015

\section{INSTRUMEN PENELITIAN \\ Keterampilan Yeop Chagi}

Keterampilan teknik yeop chagi dapat di definisikan sebagai tendangan ke arah samping. Yaitu dengan cara angkat kaki yang menendang, tekuk lutut, lalu luruskan lutut yang di tekuk miringkan badan berlawanan arah dengan sasaran dan tendang sasaran menggunakan pisau kaki. Dalam pengambilan data variabel keterampilan yeop chagi yaitu dengan melihat dari segi produk dan proses. Dalam segi produk atlet akan melakukan pengulangan keterampilan yeop chagi sebanyak 10 kali tanpa henti dan akan dicatat waktunya, atlet mendapatkan 2 kali kesempatan.

\section{Daya Ledak Otot Tungkai}

daya Ledak otot tungkai yang dalam hal ini melakukan tendangan adalah kemampuan melontarkan tendangan kearah sasaran dengan menggunakan salah satu tungkai kaki dengan cepat dengan kekuatan yang maksimal. Posisi kaki yang tidak diangkat tegak lurus namun posisi kaki menjadi eversion 90 derajat, yakni aksi yang terjadi di seputar sumbu anteposterior (AP) pada engkel kaki, kemudian melakukan lepasan tungkai bawah kearah sasaran, selanjutnya kembali keposisi awal. Daya ledak otot ditunjukkan oleh skor terbaik yang diperoleh melalui tes daya ledak otot sebanyak 3 kali percobaan.

\section{Keseimbangan}

Keseimbangan dapat berupa keseimbangan statis (static balance) pada saat berdiri maupun keseimbangan dinamis (dynamic balance) pada saat melakukan suatu gerakan tertentu. Keseimbangan statis diartikan sebagai kemampuan seseorang untuk mempertahankan posisi disuatu tempat. Sedangkan keseimbangan dinamis adalah kemampuan seseorang untuk mempertahankan keseimbangan selama melakukan berbagai gerakan seperti berjalan, berlari, melompat, menendang, dan sebagainya. Dalam hal ini peserta tes akan di tes dengan instrument tes stroke stand.

\section{Motivasi}

Motivasi merupakan keinginan, hasrat motor penggerak dalam diri manusia, motivasi berhubungan dengan faktor psikologi manusia yang mencerminkan antara sikap, kebutuhan, dan kepuasan yang 
terjadi pada diri manusia sedangkan daya dororng yang di luar diri seseorang ditimbulkan oleh pimpinan. Motivasi mempersoalkan bagaimana cara mengarahkan daya dan potensi bawahan, agar mau bekerjasama secara produktif sehingga dapat mencapai dan mewujudkan tujuan gerakan yang telah ditentukan.

\section{HASIL PEMBAHASAN}

Penelitian ini meliputi variabel terikat yaitu: Keterampilann Yeop Chagi $(\mathrm{Y})$, dan 3 variabel bebas yaitu: Daya Ledak Otot Tungkai $\left(\mathrm{X}_{1}\right)$, Keseimbangan $\left(\mathrm{X}_{2}\right)$ dan Motivasi $\left(\mathrm{X}_{3}\right)$.

\section{Data Keterampilan Yeop Chagi}

Data keterampilan yeop chagi $(\mathrm{Y})$ yaitu data yang diambil pada saat teste melakukan tendangan dengan dinilai secara proses yaitu penilaian teknik dan penilaian produk dengan melihat waktu dari hasil tendangan. Untuk menjadikan sebuah hasil masing-masing nilai dijadikan $t$-score. Kemudian $t$-score tersebut dijumlahkan. Dari hasil penjumlahan maka didapat hasil keterampilan yeop chagi (Y) sebagai berikut:

Tabel 1. data keterampilan Yeop Chagi

\begin{tabular}{|c|c|c|c|c|c|}
\hline \multicolumn{2}{|c|}{$\begin{array}{c}\text { Kelas } \\
\text { Interval }\end{array}$} & \multirow{2}{*}{$\begin{array}{c}\begin{array}{c}\text { Batas } \\
\text { Bawa } \\
\mathbf{h}\end{array} \\
1,88\end{array}$} & \multirow{2}{*}{$\begin{array}{c}\text { Bat } \\
\text { as } \\
\text { Ata } \\
\mathbf{S} \\
2,04\end{array}$} & \multirow{2}{*}{$\begin{array}{l}\text { F. } \\
\text { A } \\
4\end{array}$} & \multirow{2}{*}{$\begin{array}{c}\text { F.R } \\
16,7 \\
\%\end{array}$} \\
\hline $\begin{array}{c}1,8 \\
8\end{array}$ & $\begin{array}{c}2,0 \\
-\quad 4\end{array}$ & & & & \\
\hline $\begin{array}{c}2,0 \\
5\end{array}$ & $\begin{array}{c}2,2 \\
-\quad 1\end{array}$ & 2,05 & 2,21 & 7 & $\begin{array}{c}29,2 \\
\%\end{array}$ \\
\hline $\begin{array}{c}2,2 \\
2\end{array}$ & $\begin{array}{c}2,3 \\
-\quad 8 \\
\end{array}$ & 2,22 & 2,38 & 3 & $\begin{array}{c}12,5 \\
\%\end{array}$ \\
\hline $\begin{array}{c}2,3 \\
9\end{array}$ & $\begin{array}{c}2,5 \\
-\quad 5 \\
\end{array}$ & 2,39 & 2,55 & 2 & $8,3 \%$ \\
\hline $\begin{array}{c}2,5 \\
6\end{array}$ & $\begin{array}{c}2,7 \\
2\end{array}$ & 2,56 & 2,72 & 4 & $\begin{array}{c}16,7 \\
\%\end{array}$ \\
\hline $\begin{array}{c}2,7 \\
3\end{array}$ & $\begin{array}{c}2,8 \\
-\quad 9\end{array}$ & 2,73 & 2,89 & 4 & $\begin{array}{c}16,7 \\
\%\end{array}$ \\
\hline \multicolumn{4}{|c|}{ Jumlah } & 24 & $\begin{array}{c}100 \\
\%\end{array}$ \\
\hline
\end{tabular}

\section{Data Daya Ledak Otot Tungkai}

Data daya ledak otot tungkai $\left(\mathrm{X}_{1}\right)$ diambil dengan menggunakan tes daya ledak otot tungkai.
Tabel 2. Data Daya Ledak Otot Tungkai

\begin{tabular}{|c|c|c|c|c|c|}
\hline \multicolumn{2}{|c|}{$\begin{array}{c}\text { Kelas } \\
\text { Interval }\end{array}$} & $\begin{array}{c}\text { Batas } \\
\text { Bawa } \\
\text { h }\end{array}$ & $\begin{array}{l}\text { Bata } \\
\text { s } \\
\text { Atas }\end{array}$ & $\begin{array}{l}\text { F. } \\
\text { A }\end{array}$ & F.R \\
\hline $\begin{array}{l}3, \\
2\end{array}$ & $\begin{array}{r}-3 \\
-\quad 3\end{array}$ & 3,15 & 3,45 & 3 & $\begin{array}{c}12,5 \\
\%\end{array}$ \\
\hline $\begin{array}{l}3, \\
5\end{array}$ & $\begin{array}{r}3 \\
-\quad 7\end{array}$ & 3,45 & 3,75 & 5 & $\begin{array}{c}20,8 \\
\%\end{array}$ \\
\hline $\begin{array}{l}3, \\
8\end{array}$ & $\begin{array}{r}4 \\
-\quad 1\end{array}$ & 3,75 & 4,05 & 3 & $\begin{array}{c}12,5 \\
\%\end{array}$ \\
\hline $\begin{array}{c}4, \\
1\end{array}$ & $\begin{array}{r}4 \\
-\quad 3\end{array}$ & 4,05 & 4,35 & 3 & $\begin{array}{c}12,5 \\
\%\end{array}$ \\
\hline $\begin{array}{r}4, \\
4\end{array}$ & $\begin{array}{r}4 \\
-\quad 6 \\
\end{array}$ & 4,35 & 4,65 & 4 & $\begin{array}{c}16,7 \\
\%\end{array}$ \\
\hline $\begin{array}{l}4, \\
7\end{array}$ & $\begin{array}{r}4 \\
-\quad 9\end{array}$ & 4,65 & 4,95 & 6 & $\begin{array}{c}25,0 \\
\%\end{array}$ \\
\hline \multicolumn{4}{|c|}{ Jumlah } & 24 & $\begin{array}{c}100 \\
\%\end{array}$ \\
\hline
\end{tabular}

3. Data Keseimbangan

Data keseimbangan $\left(\mathrm{X}_{2}\right)$ diambil dengan menggunakan tes Standing Stork Test Jump.

Tabel 3. Data Keseimbangan

\begin{tabular}{|c|c|c|c|c|c|}
\hline \multicolumn{2}{|c|}{$\begin{array}{c}\text { Kelas } \\
\text { Interval }\end{array}$} & $\begin{array}{c}\text { Batas } \\
\text { Bawa } \\
\text { h }\end{array}$ & $\begin{array}{l}\text { Bata } \\
\text { s } \\
\text { Atas }\end{array}$ & $\begin{array}{l}\text { F. } \\
\text { A }\end{array}$ & F.R \\
\hline $\begin{array}{l}5 \\
1\end{array}$ & $\begin{array}{r}5 \\
-\quad 4\end{array}$ & 50,5 & 54,5 & 3 & $\begin{array}{c}12,5 \\
\%\end{array}$ \\
\hline $\begin{array}{l}5 \\
5 \\
\end{array}$ & $\begin{array}{r}5 \\
-\quad 8 \\
\end{array}$ & 54,5 & 58,5 & 6 & $\begin{array}{c}25,0 \\
\%\end{array}$ \\
\hline $\begin{array}{l}5 \\
9 \\
\end{array}$ & $\begin{array}{r}6 \\
-\quad 2 \\
\end{array}$ & 58,5 & 62,5 & 1 & $4,2 \%$ \\
\hline $\begin{array}{l}6 \\
3 \\
\end{array}$ & $\begin{array}{r}6 \\
-\quad 6 \\
\end{array}$ & 62,5 & 66,5 & 5 & $\begin{array}{c}20,8 \\
\%\end{array}$ \\
\hline $\begin{array}{l}6 \\
7\end{array}$ & $\begin{array}{r}7 \\
-\quad 0\end{array}$ & 66,5 & 70,5 & 1 & $4,2 \%$ \\
\hline $\begin{array}{l}7 \\
1 \\
\end{array}$ & $\begin{array}{r}7 \\
-\quad 4 \\
\end{array}$ & 70,5 & 74,5 & 8 & $\begin{array}{c}33,3 \\
\%\end{array}$ \\
\hline \multicolumn{4}{|c|}{ Jumlah } & 24 & $100 \%$ \\
\hline
\end{tabular}

\section{Data Motivasi}

Data Motivasi $\left(\mathrm{X}_{3}\right)$ diambil dengan menggunakan angket atau kuisioner. Dari data yang ada kemudian dijumlahkan menjadi $t$-score. 
Tabel 4. Data Motivasi

\begin{tabular}{|c|c|c|c|c|c|}
\hline \multicolumn{2}{|c|}{$\begin{array}{l}\text { Kelas } \\
\text { Interval }\end{array}$} & $\begin{array}{l}\text { Bts } \\
\text { Bwh }\end{array}$ & $\begin{array}{l}\text { Bts } \\
\text { Attas }\end{array}$ & F. & F.R \\
\hline $\begin{array}{c}13 \\
2 \\
\end{array}$ & $\begin{array}{c}13 \\
-\quad 6\end{array}$ & $\begin{array}{c}131 \\
5\end{array}$ & $\begin{array}{c}136 \\
5\end{array}$ & 7 & $\begin{array}{c}29,2 \\
\%\end{array}$ \\
\hline $\begin{array}{c}13 \\
7\end{array}$ & $\begin{array}{c}14 \\
-\quad 1\end{array}$ & $\begin{array}{c}136, \\
5\end{array}$ & $\begin{array}{c}141, \\
5\end{array}$ & 5 & $\begin{array}{c}20,8 \\
\%\end{array}$ \\
\hline $\begin{array}{c}14 \\
2\end{array}$ & $\begin{array}{c}14 \\
-\quad 6\end{array}$ & $\begin{array}{c}141, \\
5\end{array}$ & $\begin{array}{c}146, \\
5\end{array}$ & 7 & $\begin{array}{c}29,2 \\
\%\end{array}$ \\
\hline $\begin{array}{c}14 \\
7 \\
\end{array}$ & $\begin{array}{c}15 \\
-\quad 1 \\
\end{array}$ & $\begin{array}{c}146, \\
5\end{array}$ & $\begin{array}{c}151, \\
5\end{array}$ & 1 & $4,2 \%$ \\
\hline $\begin{array}{c}15 \\
2\end{array}$ & $\begin{array}{c}15 \\
-\quad 6 \\
\end{array}$ & $\begin{array}{c}151, \\
5\end{array}$ & $\begin{array}{c}156 \\
5\end{array}$ & 3 & $\begin{array}{c}12,5 \\
\%\end{array}$ \\
\hline $\begin{array}{c}15 \\
7\end{array}$ & $\begin{array}{cc}16 \\
-\quad 1 \\
\end{array}$ & $\begin{array}{c}156, \\
5\end{array}$ & $\begin{array}{c}161 \\
5\end{array}$ & 1 & $4,2 \%$ \\
\hline & 4 & $100 \%$ \\
\hline
\end{tabular}

Tabel 5. Rangkuman Hasil Deskripsi Data Penelitian

\begin{tabular}{lcccc}
\hline $\begin{array}{l}\text { Variabel } \\
\text { Parameter }\end{array}$ & $\mathrm{Y}$ & $\mathrm{X}_{1}$ & $\mathrm{X}_{2}$ & $\mathrm{X}_{3}$ \\
\hline Sampel (n) & 24 & 24 & 24 & 24 \\
\hline $\begin{array}{l}\text { Data } \\
\text { tertinggi }\end{array}$ & $\begin{array}{c}2,8 \\
8\end{array}$ & 4,9 & 74 & 160 \\
\hline $\begin{array}{l}\text { Data } \\
\text { terendah }\end{array}$ & $\begin{array}{c}1,8 \\
8\end{array}$ & 3,2 & 51 & 132 \\
\hline Rata-rata & $\begin{array}{c}2,3 \\
7\end{array}$ & $\begin{array}{c}4,1 \\
1\end{array}$ & $\begin{array}{c}63,6 \\
9\end{array}$ & $\begin{array}{c}141.6 \\
3\end{array}$ \\
\hline $\begin{array}{l}\text { Simpanga } \\
\text { n baku }\end{array}$ & 0,3 & $\begin{array}{c}0,5 \\
3\end{array}$ & $\begin{array}{c}7,78 \\
8,39\end{array}$ \\
\hline Median & $\begin{array}{c}2,2 \\
7\end{array}$ & $\begin{array}{c}4,1 \\
5\end{array}$ & 66 & 142 \\
\hline Modus & 2 & 3,7 & 66 & 132 \\
\hline
\end{tabular}

\section{Pengujian Persyaratan Analisis Data}

Sebelum dilakukan pengujian hipotesis, terlebih dahulu dilakukan pengujian persyaratan analisis. Pengujian persyaratan analisis meliputi:

a. Uji Normalitas

Untuk menguji normal tidaknya sampel yang digunakan dalam penelitian ini digunakan uji Lillifors. Pada taraf signifikasi $\alpha=0,05$ data yang digunakan terdapat pada lampiran adalah merupakan data hasil dari variabel yang ada. Data perhitungan terhadap data variabel penelitian dapat dilihat dalam tabel berikut ini:

Tabel 6. Rangkuman Hasil Uji Normalitas Data Dengan Uji Lillifors

\begin{tabular}{ccccc}
\hline Variabel & $\mathrm{N}$ & $\mathrm{L}_{\mathrm{h}}$ & $\mathrm{L}_{\text {tab }}$ & Kes. \\
\hline $\mathrm{Y}$ & 30 & 0,141 & 0,177 & Normal \\
\hline $\mathrm{X}_{1}$ & 30 & 0,138 & 0,177 & Normal \\
\hline $\mathrm{X}_{2}$ & 30 & 0,175 & 0,177 & Normal \\
\hline $\mathrm{X}_{3}$ & 30 & 0,175 & 0,177 & Normal \\
\hline
\end{tabular}

Keterangan:

$\mathrm{Y}=$ Keterampilan Yeop Chagi

$\mathrm{X}_{1} \quad$ = Daya ledak otot tungkai

$\mathrm{X}_{2}=$ Keseimbangan

$\mathrm{X}_{3} \quad=$ Motivasi

Tabel diatas memberikan informasi bahwa harga $L_{\text {hitung }}$ untuk keempat variabel lebih kecil dari pada harga $\mathrm{L}_{\text {tabel }}$ pada taraf signifikansi $\alpha=0,05$, ini berarti bahwa sampel penelitian ini berasal dari kelompok yang berdistribusi normal.

b. Uji Homogenitas

Untuk mengetahui masing-masing variabel memiliki varians yang sama, maka dilakukan uji homogenitas dengan menggunakan uji bartlett. Kriteria pengujian adalah diterima Ho Jika $\mathrm{X}^{2}$ hitung $<\mathrm{X}^{2}$ tabel pada taraf signifikansi $\alpha=0,05$ dengan $\mathrm{dk}(\mathrm{k}=3)$. Pada taraf nyata $\alpha=0,05$ diperoleh $\mathrm{X}_{\text {tabel }}^{2}=$ 7,81 ternyata $X^{2}{ }_{\text {hitung }}<X^{2}$ tabel yaitu $1,960<$ 7,81, sehingga dapat disimpulkan bahwa data penelitian memiliki varians populasi homogen.

\section{Pengujian Hipotesis}

1. Hubungan antara Daya ledak otot Tungkai $\left(\mathrm{X}_{1}\right)$ dengan Keterampilan Yeop Chagi (Y)

Dalam penelitian ini, hipotesis pertama yang diuji adalah: terdapat hubungan positif antara daya ledak otot tungkai dengan keterampilan yeop chagi). Untuk pengujian hipotesis ini maka disusun hipotesis sebagai berikut:

$\begin{aligned} \text { Ho: } \mathrm{P}_{\mathrm{y} .1}=0 & \mathrm{H}_{1}: \mathrm{P}_{\mathrm{y} .1}=0 \\ \text { Pengujian } & \text { hipotesis }\end{aligned}$ menggunakan analisis regresi sederhana dan korelasi sederhana. Dari hasil perhitungan diperoleh persamaan regresi yang dinyatakan melalui persamaan: $\tilde{Y}=6,03+$ 
$0,879 \mathrm{X}_{1}$, selanjutnya persamaan ini telah diuji keberartiannya untuk menyakinkan kesimpulan. Dari hasil perhitungan dengan uji $\mathrm{F}$ diperoleh nilai $\mathrm{F}$ sebagaimana yang ditunjukan dalam tabel 11 pada halaman sebagai berikut:

Tabel 7. Anava Regresi Linier Sederhana $\mathrm{X}_{1}$ dan variabel $\mathrm{Y}$

\begin{tabular}{|c|c|c|c|c|c|}
\hline $\begin{array}{l}\text { Sumber } \\
\text { Varians }\end{array}$ & $\begin{array}{l}\mathbf{d} \\
\mathbf{k}\end{array}$ & JK & $\begin{array}{l}\mathbf{R J} \\
\mathbf{K}\end{array}$ & $\begin{array}{r}\mathbf{F}_{\text {hit }} \\
\text { ung }\end{array}$ & $\begin{array}{r}\mathbf{F}_{\text {ta }} \\
\text { bel }\end{array}$ \\
\hline Total & $\begin{array}{l}2 \\
4\end{array}$ & $\begin{array}{l}6230 \\
0,00\end{array}$ & & & \\
\hline $\begin{array}{l}\text { Regresi } \\
\text { (a) }\end{array}$ & 1 & $\begin{array}{c}6000 \\
0,00 \\
\end{array}$ & & & \\
\hline $\begin{array}{l}\text { Regresi } \\
\text { (b/a) }\end{array}$ & 1 & $\begin{array}{c}1778, \\
92\end{array}$ & $\begin{array}{l}177 \\
8,92\end{array}$ & 75 , & 4, \\
\hline Sisa & $\begin{array}{l}2 \\
2 \\
\end{array}$ & $\begin{array}{c}521,0 \\
8\end{array}$ & $\begin{array}{c}23,6 \\
9\end{array}$ & 11 & 17 \\
\hline $\begin{array}{l}\text { Tuna } \\
\text { Cocok }\end{array}$ & $\begin{array}{l}1 \\
2\end{array}$ & $\begin{array}{c}359,7 \\
3\end{array}$ & $\begin{array}{c}29,9 \\
8\end{array}$ & & \\
\hline $\begin{array}{c}\text { Galat } \\
\text { Kekelirua } \\
n\end{array}$ & $\begin{array}{l}1 \\
0\end{array}$ & $\begin{array}{c}161,3 \\
6\end{array}$ & $\begin{array}{c}16,1 \\
4\end{array}$ & $\begin{array}{c}1,8 \\
6\end{array}$ & $\begin{array}{l}2, \\
91\end{array}$ \\
\hline
\end{tabular}

\section{Keterangan:}

DK = Derajat Kebebasan

JK = Jumlah Kuadrat

RJk = Rata-rata Jumlah Kuadrat

$\mathrm{F}_{\mathrm{h}} \quad=\mathrm{F}_{\text {hitung }}$

$\mathrm{F}_{\mathrm{t}} \quad=\mathrm{F}_{\text {tabel }}$

Dari analisis varians diperoleh $\mathrm{F}_{\text {hitung }}$ $=75,11$ sedangkan $F_{\text {tabel }}=4,17$ dengan taraf signifikansi $\alpha=0,05$, sehingga dapat disimpulkan bahwa regresi $\mathrm{X}_{1}$ dengan $\mathrm{Y}$ signifikan. Pada pengujian linieritas dalam tabel di atas ternyata $F_{\text {hitung }}<F_{\text {tabel }}$ yaitu 1,86 $<2,91$ pada taraf signifikansi $=0,05$. Sehingga dapat disimpulkan bahwa bentuk regresi $\mathrm{X}_{1}$ dengan $\mathrm{Y}$ adalah linier.

Dari analisis korelasi sederhana diperoleh hasil perhitungan $(\mathrm{r})=0,88$ dengan koefesien determinasi $\left(\mathrm{r}^{2}\right)=77,34$ $\%$. Koefesien korelasi sederhana ini ternyata sangat signifikan setelah dilakukan pengujian keberartian dengan uji $-\mathrm{t}$ pada $\alpha=$ 0,05 dengan derajat kebebasan $(\mathrm{dk})=22$. Hal ini ditunjukkan oleh hasil pengujian $\mathrm{t}_{\text {hitung }}>$ $\mathrm{t}$ tabel yaitu 8,67>1,70 maka koefesien korelasi $\mathrm{X}_{1}$ dengan $\mathrm{Y}$ sangat signifikan.

Dengan demikian menunjukkan bahwa terdapat hubungan positif antara daya ledak otot tungkai $\left(\mathrm{X}_{1}\right)$ dengan keterampilan yeop chagi $(\mathrm{Y})$. Kekuatan antara variabel $\mathrm{X}_{1}$ dengan variabel $\mathrm{Y}$ ini ditunjukkan oleh hasil pengujian koefesien korelasi (r) sebesar $=$ 0,879 dan koefesien determinasi $\left(\mathrm{r}^{2}\right)$ sebesar $=0,7734$. Karena itu hipotesis nol ditolak, ini berarti bahwa hipotesis penelitian ini diterima. Dengan demikian hasil penelitian ini dapat disimpulkan bahwa terdapat hubungan positif antara daya ledak otot tungkai dengan keterampilan yeop chagi.

\section{Hubungan Antara Keseimbangan $\left(X_{2}\right)$ Dengan Keterampilan Yeop Chagi (Y)}

Dalam penelitian ini, hipotesis pertama yang diuji adalah: terdapat hubungan positif antara keseimbangan dengan keterampilan yeop chagi). Untuk pengujian hipotesis ini maka disusun hipotesis sebagai berikut:

Ho: $\mathrm{Py}_{.2}=0 \quad \mathrm{H}_{1}: \mathrm{Py}_{.2}=0$

Pengujian hipotesis ini menggunakan analisis regresi sederhana dan korelasi sederhana. Dari hasil perhitungan diperoleh persamaan regresi yang dinyatakan melalui persamaan: $\tilde{Y}=19,86+$ $0,603 \mathrm{X}_{2}$, selanjutnya persamaan ini telah diuji keberartian dan kelinierannya untuk meyakinkan pengambilan kesimpulan. Dari hasil perhitungan uji $\mathrm{F}$ diperoleh nilai $\mathrm{F}$ sebagaimana yang ditunjukkan dalam tabel 8 pada halaman sebagai berikut:

Tabel 8. Anava Regresi Linier Sederhana $\mathrm{X}_{2}$ dan variabel $\mathrm{Y}$

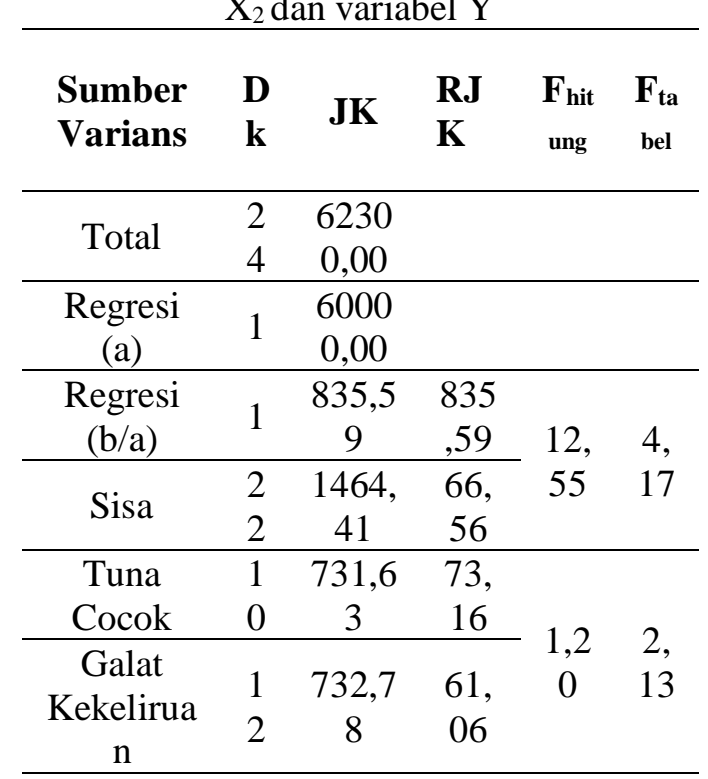

Keterangan:

DK = Derajat Kebebasan

JK = Jumlah Kuadrat 
RJk = Rata-rata Jumlah Kuadrat

$\mathrm{F}_{\mathrm{h}} \quad=\mathrm{F}_{\text {hitung }}$

$\mathrm{F}_{\mathrm{t}} \quad=\mathrm{F}_{\text {tabel }}$

Dari analisis varians diperoleh $\mathrm{F}_{\text {hitung }}$ $=12,55$, sedangkan $F_{\text {tabel }}=4,17$, dengan taraf signifikansi $\alpha=0,05$. Sehingga dapat disimpulkan bahwa regresi $\mathrm{X}_{2}$ dengan $\mathrm{Y}$ signifikan. Pada pengujian linieritas dalam tabel diatas ternyata $F_{\text {hitung }}<\mathrm{F}_{\text {tabel }}$ yaitu 1,20 $<2,13$ pada taraf signifikansi $=0,05$. Sehingga dapat disimpulkan bahwa bentuk regresi $\mathrm{X}_{2}$ dengan $\mathrm{Y}$ adalah linier.

Dari analisis korelasi sederhana diperoleh hasil perhitungan $(r)=0,603$, dengan koefesien determinasi 0,3633. Koefesien korelasi sederhana ini ternyata sangat signifikan setelah dilakukan pengujian keberartian dengan uji - t pada $\alpha$ $=0,05$ dengan derajat kebebasan $(\mathrm{dk})=22$. Hal ini ditunjukkan oleh hasil pengujian $t_{\text {hitung }}$ sebesar $=3,10$ dan $t_{\text {tabel }}$ sebesar $=1,70$ Karena $t_{\text {hitung }}>t_{\text {tabel }}$ yaitu 3,54 $>1,70$ maka koefesien korelasi $\mathrm{X}_{2}$ dengan $\mathrm{Y}$ sangat signifikan.

Dengan demikian menunjukkan bahwa terdapat hubungan positif antara keseimbngan $\left(\mathrm{X}_{2}\right)$ dengan keterampilan yeop chagi $(\mathrm{Y})$. Kekuatan hubungan antara variabel $\mathrm{X}_{2}$ dengan variabel $\mathrm{Y}$ ini ditunjukkan oleh hasil pengujian koefesien korelasi (r) sebesar 0,603, dan koefesien determinasi $\left(\mathrm{r}^{2}\right)$ sebesar $36,33 \%$. Karena itu hipotesis nol ditolak, ini berarti bahwa hipotesis penelitian ini diterima. Dengan demikian hasil penelitian ini dapat disimpulkan bahwa terdapat hubungan positif antara keseimbangan dengan keterampilan yeop chagi.

\section{Hubungan Antara Motivasi Dengan Keterampilan Yeop Chagi}

$\left(\mathbf{X}_{3}\right)$

Dalam penelitian ini, hipotesis pertama yang diuji adalah: terdapat hubungan positif antara Motivasi dengan Keterampilan Yeop Chagi. Untuk pengujian hipotesis ini maka disusun hipotesis sebagai berikut:

Ho: $\mathrm{P}_{\mathrm{y} .1}=0 \quad \mathrm{H}_{1}: \mathrm{P}_{\mathrm{y} .1}=0$

Pengujian hipotesis ini

menggunakan analisis regresi sederhana dan korelasi sederhana. Dari hasil perhitungan diperoleh persamaan regresi yang dinyatakan melalui persamaan: $\tilde{Y}=18,32+$
$0,634 X_{3}$, selanjutnya persamaan ini telah diuji keberartiannya untuk menyakinkan kesimpulan. Dari hasil perhitungan dengan uji $\mathrm{F}$ diperoleh nilai $\mathrm{F}$ sebagaimana yang ditunjukan dalam tabel 13 pada halaman sebagai berikut:

Tabel 9. Anava Regresi Linier Sederhana $\mathrm{X}_{3}$ dan variabel $\mathrm{Y}$

\begin{tabular}{|c|c|c|c|c|c|}
\hline $\begin{array}{l}\text { Sumber } \\
\text { Varians }\end{array}$ & $\begin{array}{l}\mathbf{d} \\
\mathbf{k}\end{array}$ & JK & $\begin{array}{l}\mathbf{R J} \\
\mathbf{K}\end{array}$ & $\mathbf{F}_{\text {hit }}$ & $\mathbf{F}_{\mathbf{t}}$ \\
\hline Total & $\begin{array}{l}2 \\
4\end{array}$ & $\begin{array}{r}6230 \\
0,00\end{array}$ & & & \\
\hline $\begin{array}{l}\text { Regresi } \\
\text { (a) }\end{array}$ & 1 & $\begin{array}{r}6000 \\
0,00 \\
\end{array}$ & & & \\
\hline $\begin{array}{l}\text { Regresi } \\
\text { (b/a) }\end{array}$ & 1 & $\begin{array}{r}923,2 \\
1 \\
\end{array}$ & $\begin{array}{r}923, \\
21 \\
\end{array}$ & 14, & 4 \\
\hline Sisa & $\begin{array}{l}2 \\
2 \\
\end{array}$ & $\begin{array}{r}1376, \\
79 \\
\end{array}$ & $\begin{array}{r}62,5 \\
8 \\
\end{array}$ & 75 & 17 \\
\hline $\begin{array}{c}\text { Tuna } \\
\text { Cocok } \\
\end{array}$ & 8 & $\begin{array}{r}2605, \\
38 \\
\end{array}$ & $\begin{array}{r}325, \\
67 \\
\end{array}$ & - & \\
\hline $\begin{array}{c}\text { Galat } \\
\text { Kekelirua } \\
\mathrm{n}\end{array}$ & $\begin{array}{l}1 \\
4\end{array}$ & $\begin{array}{r}- \\
1228, \\
59\end{array}$ & $\begin{array}{r}- \\
87,7 \\
6\end{array}$ & $\begin{array}{r}3,7 \\
1\end{array}$ & $\begin{array}{r}2, \\
60\end{array}$ \\
\hline
\end{tabular}

Keterangan:

DK = Derajat Kebebasan

JK = Jumlah Kuadrat

RJk = Rata-rata Jumlah Kuadrat

Fh $\quad=F_{\text {hitung }}$

$\mathrm{Ft} \quad=\mathrm{F}_{\text {tabel }}$

Dari analisis varians diperoleh $F_{\text {hitung }}$ $=14,75$ sedangkan $F_{\text {tabel }}=4,17$ dengan taraf signifikansi $\alpha=0,05$, sehingga dapat disimpulkan bahwa regresi $\mathrm{X}_{1}$ dengan $\mathrm{Y}$ signifikan. Pada pengujian linieritas dalam tabel di atas ternyata $F_{\text {hitung }}<F_{\text {tabel }}$ yaitu $-3,71$ $<2,60$ pada taraf signifikansi $=0,05$. Sehingga dapat disimpulkan bahwa bentuk regresi $\mathrm{X}_{3}$ dengan $\mathrm{Y}$ adalah linier.

Dari analisis korelasi sederhana diperoleh hasil perhitungan $(r)=0,634$ dengan koefesien determinasi $\left(r^{2}\right)=40,14$ $\%$. Koefesien korelasi sederhana ini ternyata sangat signifikan setelah dilakukan pengujian keberartian dengan uji - t pada $\alpha$ $=0,05$ dengan derajat kebebasan $(\mathrm{dk})=22$. Hal ini ditunjukkan oleh hasil pengujian $t$ hitung $>t_{\text {tabel }}$ yaitu 3,84>1,70 maka koefesien korelasi $\mathrm{X}_{1}$ dengan $\mathrm{Y}$ sangat signifikan.

Dengan demikian menunjukkan bahwa terdapat hubungan positif antara Motivasi $\left(\mathrm{X}_{3}\right)$ dengan keterampilan yeop 
chagi (Y). Kekuatan antara variabel $\mathrm{X}_{3}$ dengan variabel $\mathrm{Y}$ ini ditunjukkan oleh hasil pengujian koefesien korelasi (r) sebesar $=$ 0,634 dan koefesien determinasi $\left(\mathrm{r}^{2}\right)$ sebesar $=40,14 \%$. Karena itu hipotesis nol ditolak, ini berarti bahwa hipotesis penelitian ini diterima. Dengan demikian hasil penelitian ini dapat disimpulkan bahwa terdapat hubungan positif antara Motivasi dengan keterampilan yeop chagi.

4. Hubungan antara daya ledak otot tungkai $\left(X_{1}\right)$, keseimbangan $\left(X_{2}\right)$ dan Motivasi $\left(\mathrm{X}_{3}\right)$ dengan keterampilan yeop chagi (Y)

Dalam penelitian ini, hipotesis pertama yang diuji adalah: terdapat hubungan positif antara daya ledak otot tungkai, keseimbangan dan motivasi dengan keterampilan yeop chagi. Untuk pengujian hipotesis ini maka disusun hipotesis sebagai berikut:

$\begin{array}{cc}\text { Ho: } \mathrm{Ry}_{1.2 .3}=0 \\ \text { Pengujian } & \begin{array}{c}\mathrm{H}_{1}: \mathrm{Ry}_{1.2 .3}=0 \\ \text { hipotesis }\end{array} \text { ini }\end{array}$ menggunakan analisis regresi sederhana dan korelasi sederhana. Dari hasil perhitungan diperoleh persamaan regresi yang dinyatakan melalui persamaan:

$\tilde{Y}=a+b_{1} X_{2}+b_{2} X_{2}+b_{3} X_{3}$

$\tilde{\mathrm{Y}} \quad=$ Keterampilan yeop chagi

$\mathrm{X}_{1} \quad=$ Daya ledak otot tungkai

$\mathrm{X}_{2} \quad=$ Keseimbangan

$\mathrm{X}_{3} \quad=$ Motivasi

a $\quad=$ Konstanta Untuk Sampel

b = Koefesien Regresi

Dari hasil perhitungan diperoleh masing-masing harga $a=10,931 b_{1}=0,441$; $b_{2}=0,514 ; b_{3}=-0,1775$ Dengan demikian model regresi ganda adalah $\hat{\mathrm{Y}}=11,125+$ $0,882 \mathrm{X}_{1}+1,027 \mathrm{X}_{2}-0,355 \mathrm{X}_{3}$.

Selanjutnya dilakukan uji keberartian terhadap koefesien regresi ganda dengan uji $\mathrm{F}$, yang diperoleh $\mathrm{F}_{\text {hitung }}$ sebesar $=$ 19,52 pada taraf $\alpha=0,05$ dengan derajat kebebasan (dk) pembilang $=2 \mathrm{dan} \mathrm{dk}$, penyebut $(n-3)=20$ diperoleh $F_{\text {tabel }}$ sebesar 3,10. Karena $F_{\text {hitung }}>F_{\text {tabel }}$ yaitu $14,12>3,10$ maka koefesien korelasi ganda adalah signifikan.

Dari analisis korelasi ganda diperoleh hasil perhitungan koefesien korelasi ganda $\left(\mathrm{Ry}_{1.2 .3}\right)$ sebesar0,692dan koefesien determinasi $\left(\mathrm{Ry}_{1.2 .3^{2}}\right)$ sebesar $86,31 \%$ Selanjutnya dilakukan uji keberartian terhadap koefesien korelasi ganda dengan mengadakan uji F. Dari perhitungan diperoleh $\mathrm{F}_{\text {hitung }}$ sebesar 14,12 pada taraf $\alpha=0,05$ dengan derajat kebebasan (dk) pembilang $=2$ dan $(\mathrm{dk})$ penyebut $(\mathrm{n}-$ 3 ) $=27$ diperoleh $F_{\text {tabel }}$ sebesar 2,89. Karena $\mathrm{F}_{\text {hitung }}>\mathrm{F}_{\text {tabel }}$ yaitu $14,12>2,93$ maka koefesien korelasi ganda adalah signifikan. Karena itu hipotesis nol ditolak dan ini berarti hipotesis penelitian diterima.

Dengan demikian hasil penelitian ini menyimpulkan bahwa terdapat hubungan positif antara daya ledak otot tungkai, keseimbangan dan motivasi secara bersamasama dengan keterampilan yeop chagi. Kekuatan antara variabel $\mathrm{X}_{1}, \mathrm{X}_{2}$ dan $\mathrm{X}_{3}$ dengan variabel $\mathrm{Y}$ ini ditunjukkan oleh koefesien korelasi ganda (r) sebesar 0,745. Kemudian dari koefesien determinasi $\left(\mathrm{r}^{2}\right)$ sebesar $86,31 \%$, ini berarti bahwa variasi yang terjadi pada hasil keterampilan yeop chagi sebesar $59,4 \%$ ditentukan secara bersama-sama oleh daya ledak otot tungkai, keseimbanga dan motivasi melalui model regresi ganda $\tilde{Y}=10,931+0,343 X_{1}+0,102$ $\mathrm{X}_{2}+0,336 \mathrm{X}_{3}$

Dari hasil pengujian hipotesis pertama dapat disimpulkan bahwa terdapat hubungan positif antara daya ledak otot tungkai, keseimbangan dan motivasi dengan keterampilan yeop chagi yang ditunjukkan dengan persamaan regresi linier sederhana $\tilde{Y}$ $=6,03+0,879 \mathrm{X}_{1}$ yang telah diuji keberartiannya dari persamaan ini dapat diinterpretasikan bahwa: rata-rata setiap penambahan satu unit skor kemampuan daya ledak otot tungkai $\left(\mathrm{X}_{1}\right)$ akan diikuti oleh kenaikan 0,879 unit skor keterampilan yeop $\operatorname{chagi}(\mathrm{Y})$.

Melalui pengujian korelasi sederhana dihasilkan koefesien korelasi (r) sebesar 0,879, dan koefesien determinasi 0,7734 . Hal ini berarti bahwa variasi yang terjadi pada hasil keterampilan yeop chagi $77,34 \%$ ditentukan oleh daya ledak otot tungkai dengan model regresi linier sederhana $\mathrm{Y}=6,03+0,879 \mathrm{X}_{1}$. Hubungan antara daya ledak otot tungkai dengan keterampilan yeop chagi tetap positif dan berarti setelah dilakukan pengontrolan terhadap variabel keseimbangan $\left(\mathrm{X}_{2}\right)$ 
melalui pengujian parsial $\alpha=0,05$. Hubungan antara keseimbangan dengan keterampilan yeop chagi tetap positif dan berarti setelah dilakukan pengontrolan terhadap variabel motivasi $\left(\mathrm{X}_{3}\right)$ melalui pengujian parsial $\alpha=0,05$.

Dari hasil pengujian hipotesis ini didapat kesimpulan bahwa terdapat hubungan positif antara daya ledak otot tungkai dengan keterampilan yeop chagi. Artinya makin baik tingkat daya ledak otot tungkai yang dimiliki maka akan makin baik keterampilan yeop chagi dan sebaliknya makin rendah tingkat daya ledak otot tungkai yang dimiliki maka akan semakin rendah pula keterampilan yeop chagi yang dilakukan.

Kemudian hasil pengujian hipotesis kedua dapat disimpulkan bahwa terdapat hubungan positif antara daya ledak otot tungkai dengan hasil keterampilan yeop chagi, yang ditunjukkan oleh persamaan regresi linier sederhana $Y=19,86+0,603$ $\mathrm{X}_{2}$ yang telah diuji keberartiannya. Dari persamaan ini dapat diinterpretasikan bahwa setiap penambahan satu unit skor keseimbangan $\left(\mathrm{X}_{2}\right)$ akan diikuti oleh kenaikan sebesar 0,603unit hasil keterampilan yeop chagi $(\mathrm{Y})$.

Pengajuan korelasi sederhana pada hipotesis kedua ini menghasilkan koefesien korelasi $\left(\mathrm{r}^{2}\right)$ sebesar 0,3633 hal ini berarti bahwa variasi yang terjadi pada keterampilan yeop chagi sebesar 36,33\% ditentukan oleh keseimbangan melalui model regresi sederhana $Y=19,86+0,603$ $\mathrm{X}_{2}$ yang telah diuji keberartiannya. Hubungan keseimbangan dengan keterampilan yeop chagi tetap positif dan berarti setelah dilakukan pengontrolan terhadap keseimbangan melalui pengujian korelasi parsial $\alpha=0,05$

Kemudian hasil pengujian hipotesis ketiga dapat disimpulkan bahwa terdapat hubungan positif antara motivasi dengan keterampilan yeop chagi, yang ditunjukkan oleh persamaan regresi linier sederhana $\mathrm{Y}$ $=18,32+0,634 \mathrm{X}_{3}$ yang telah diuji keberartiannya. Dari persamaan ini dapat diinterpretasikan bahwa setiap penambahan satu unit skor Motivasi $\left(\mathrm{X}_{3}\right)$ akan diikuti oleh kenaikan sebesar 0,634unit keterampilan yeop chagi $(\mathrm{Y})$.
Pengajuan korelasi sederhana pada hipotesis ketiga ini menghasilkan koefesien korelasi $\left(r^{2}\right)$ sebesar 0,634 hal ini berarti bahwa variasi yang terjadi pada keterampilan yeop chagi sebesar 40,14\% ditentukan oleh motivasi melalui model regresi sederhana $\mathrm{Y}=18,32+0,634 \mathrm{X}_{2}$ yang telah diuji keberartiannya. Hubungan antara motivasi dengan keterampilan yeop chagi tetap positif dan berarti setelah dilakukan pengontrolan terhadap motivasi melalui pengujian korelasi parsial $\alpha=0,05$

Kemudian hasil pengujian hipotesis keempat dapat disimpulkan bahwa terdapat hubungan positif antara daya ledak otot tungkai, keseimbangan dan motivasi dengan keterampilan yeop chagi, yang ditunjukkan oleh persamaan regresi linier sederhana $\tilde{Y}=$ $11,125+0,882 \mathrm{X}_{1}+1,027 \mathrm{X}_{2}-0,355 \mathrm{X}_{3}$ yang telah diuji keberartiannya.

Pengajuan korelasi ganda pada hipotesis keempat ini menghasilkan koefesien korelasi $\left(\mathrm{r}^{2}\right)$ sebesar 0,8631 hal ini berarti bahwa variasi yang terjadi pada keterampilan yeop chagi sebesar 86,31\% ditentukan oleh daya ledak otot tungkai, keseimbangan dan motivasi melalui model regresi sederhana $\mathrm{Y}=11,125+0,882 \mathrm{X}_{1}+$ $1,027 X_{2}-0,355 X_{3}$ yang telah diuji keberartiannya.

Walaupun berbagai upaya telah dilakukan untuk menghindari hal-hal yang dapat mengurangi bobot hasil penelitian, namun diakui masih terdapat beberapa keterbatasan dan kelemahan yang tidak dapat dikendalikan, yaitu:

1. Penelitian ini hanya dilakukan pada satu tempat, yaitu Pelatda Taekwondo DKI Jakarta, dengan populasi terbatas sehingga penelitian ini belum cukup digeneralisasikan ke tempat lain

2. Dalam melakukan pengambilan data penelitian ini kurang memperhatikan pada aspek berat tubuh subyek tes dan akurasi tendangan, sehingga akan lebih sempurna apabila dalam mengambil data peneliti memperhatikan unsur tersebut.

3. Dalam melakukan pengambilan data, ada kemungkinan atlet kurang mengikuti petunjuk pelaksanaan tes yang telah diberikan, sehingga ada kemungkinan data yang diperoleh 
kurang mencerminkan keadaan yang sebenarnya.

4. Tidak ada kontrol terhadap variabelvariabel lain yang dapat mempengaruhi keterampilan yeop chagi yang diperoleh, sehingga mungkin ada variabel lain yang lebih mempengaruhi hasil keterampilan yeop chagi.

\section{KESIMPULAN}

Berdasarkan hasil penelitian yang telah diuraikan di atas, maka dapat diambil kesimpulan sebagai berikut:

1. Berdasarkan hasil pengujian pertama menunjukkan bahwa terdapat hubungan positif antara daya ledak otot tungkai dengan keterampilan yeop chagi dengan persamaan garis regresi $\tilde{Y}=6,03+0,879$ $\mathrm{X}_{1}$ pada taraf signifikansi $\alpha=0,05$ dan koefesien korelasi $(r)=0,879$ dengan koefesien determinasi $\left(\mathrm{r}^{2}\right)$ 0,7734 pada taraf signifikansi $\alpha=0,05$. Dengan demikian berarti mengidentifikasikan $77,34 \%$ varians yang terjadi pada hasil tembakan melayang (flying shoot) dapat dijelaskan melalui daya ledak otot lengan.

2. Berdasarkan hasil pengujian hipotesis yang kedua menunjukkan bahwa terdapat hubungan positif antara keseimbangan dengan dengan keterampilan yeop chagi dengan persamaan garis regresi $\mathrm{Y}=$ $19,86+0,603 X_{2}$ pada taraf signifikansi $\alpha=0,05$ dan koefesien korelasi $(r)=$ 0,603 dengan koefesien determinasi $\left(\mathrm{r}^{2}\right)$ $=0,3633$. Dengan demikian maka terdapat $36,33 \%$ varian yang terjadi pada keterampilan yeop chagi dapat dijelaskan melalui keseimbangan.

3. Berdasarkan hasil pengujian hipotesis yang ketiga menunjukkan bahwa terdapat hubungan positif antara Motivasi dengan keterampilan yeop chagi dengan persamaan garis regresi $\mathrm{Y}=18,32+$ $0,634 \mathrm{X}_{3}$ pada taraf signifikansi $\alpha=0,05$ dan koefesien korelasi $(r)=0,634$ dengan koefesien determinasi $\left(\mathrm{r}^{2}\right)=0,4014$. Dengan demikian maka terdapat $40,14 \%$ varian yang terjadi pada tembakan melayang (flying shoot) dapat dijelaskan melalui Motivasi.

4. Berdasarkan hasil pengujian hipotesis keempat menunjukkan bahwa terdapat hubungan positif antara daya ledak otot tungkai, keseimbangan dan motivasi secara bersama-sama dengan keterampilan yeop chagi. Hal ini dapat ditunjukkan melalui persamaan garis regresi yaitu: $\quad \mathrm{Y}=11,125$ $+0,882 X_{1}+1,027 X_{2}-0,355 X_{3}$ pada taraf signifikansi $\quad \alpha=0,05$ dan koefesien korelasi $(\mathrm{r})=0,8631$ dan koefesien determinasi $\left(\mathrm{r}^{2}\right) \quad 0,8631$ suatu koefesien korelasi yang mengidentifikasikan $86,31 \%$ varian yang terjadi pada keterampilan yeop chagi dapat dijelaskan secara bersamasama melalui daya ledak otot tungkai, keseimbangan dan motivasi. Hal ini membuktikan bahwa hipotesis keempat dapat diterima dan berarti semakin baik (positif) daya ledak otot tungkai, keseimbangab dan motivasi, maka akan semakin baik (positif) pula keterampilan yeop chagi.

\section{DAFTAR PUSTAKA}

Bangun, Wilson. Intisari Manajemen, Bandung: Refika Aditama, 2008

Bateman, Heather. Dictionary of Sport and Exercise Science, London: A \& C Black Publisher Ltd, 2006

Bompa, Tudor. Periodization, Theory and Methodologi of Taining, HK Rewards, 2009

Brown, Lee. Training for Speed, Agility and Quickness Human Kinetik, 2006

Brown, Lee. Training for Speed, Agility and Quickness, Library of Congres Cataloging-in-Publication Data, 2005

Cassidy, Tania. Understanding Sport Coaching, New York: Taylor \& francis eLibrary, 2004

Delavier, Frederic Strength Training Anatomy, Paris: Guide des Mouvements de Musculation, 2006

Edwards, William. Motor Learning and Control, Belmont: Wadsworth, 2011

Kang, Ikpil. The Explanation of Official Taekwondo Poomsae Seoul: Shang A Publishing Company, 2008

Lee, Kyong Myong.Taekwondo Technique \& Training. New York. 1996 
McMoris, Tery. Coaching Science Theory Into Practice, West Sussex: John Willey and Sons Ltd., 2006

Meehan, Willian. Kids, Sport and Concussion, California: Praeger, 2011

Soon, Park Hae. Teknik Gerak Dasar Taekwondo. Seoul.
Susiono, Ricky. The Secret Power of Mind and Body Unification, Jakarta: Garuda Indonesia Perkasa, 2012

Tangkudung, James. Kepelatihan Olahraga. Jakarta : Cerdas Jaya. 2012

Verkhoshansky, Yuri. Special Training A Particular Manual of Coching, Moscow, 2006

Widiastuti, Tes dan Pengukuran Olahraga. Jakarta : PT. Bumi Timur Jaya. 2011 